\title{
Carbohydrates and glycosylation ${ }^{*}$
}

\author{
Patricia M. Berninsone ${ }^{\S}$, Biology Department, University of Nevada, \\ Reno, Reno, NV 89557 USA
}

\section{Table of Contents}

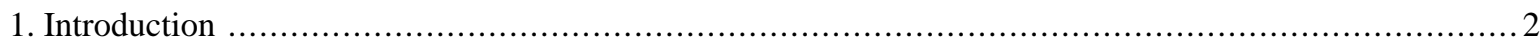

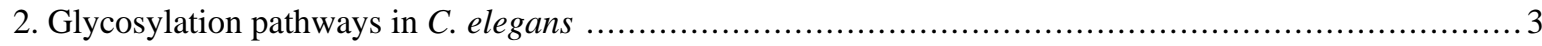

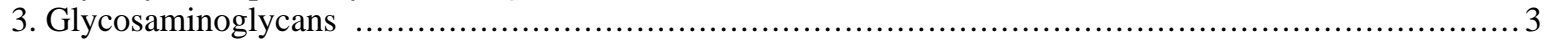

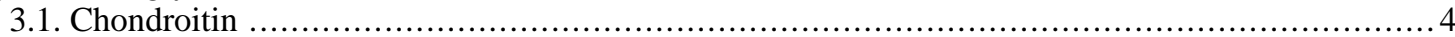

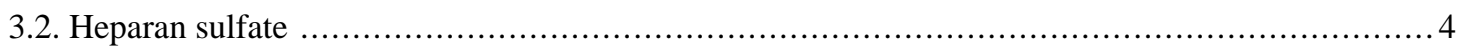

3.3. Heparan sulfate and chondroitin modified proteins ................................................... 5

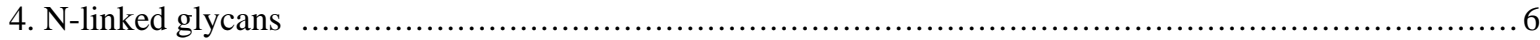

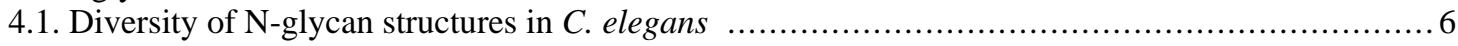

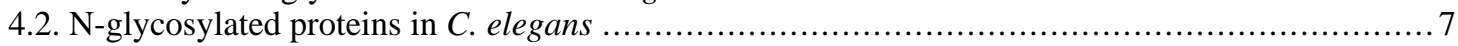

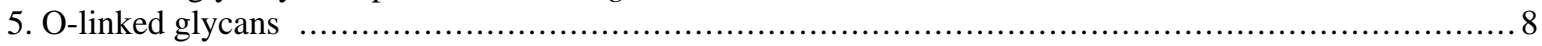

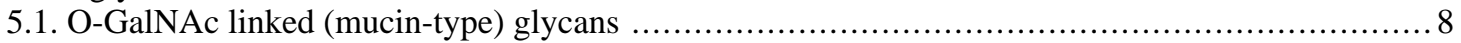

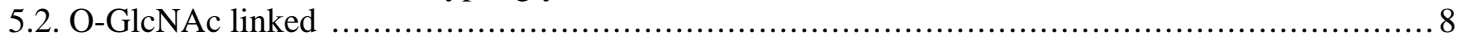

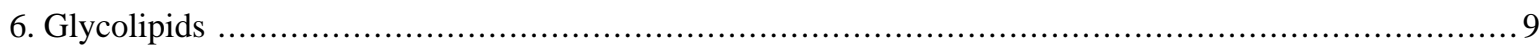

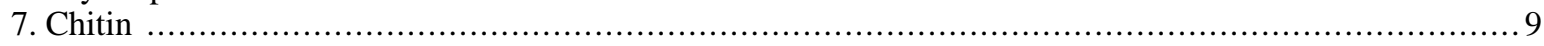

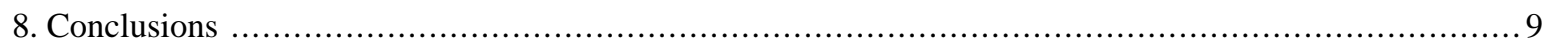

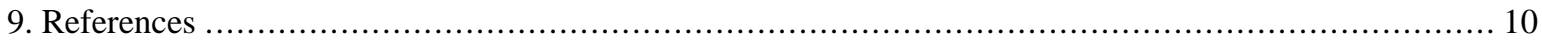

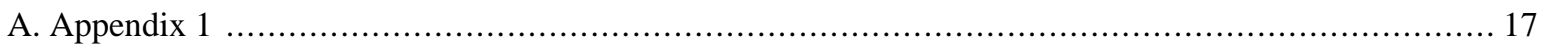

\begin{abstract}
The $C$. elegans genome contains sequences similar to a large number of mammalian genes implicated in the assembly, processing, and modification of glycans. In recent years, spectacular progress has been made in developing and refining tools to obtain structural information with small amounts of material, increasing our understanding of glycan structural complexity in this organism. These approaches have revealed novel Nand O-glycan structures in $C$. elegans, as well as a high degree of conservation in glycosaminoglycan structure. In parallel, studies in which glycan structure is perturbed by genetic manipulation have begun to reveal the roles of specific carbohydrate moieties in developmental and physiological processes. This review summarizes recent work elucidating the fine structure of complex carbohydrates in $C$. elegans as well as genetic studies that have uncovered novel roles for complex carbohydrates in developmental processes.
\end{abstract}

\footnotetext{
*Edited by Patricia Kuwabara. Last revised October 17, 2006. Published December 18, 2006. This chapter should be cited as: Berninsone, P.M. Carbohydrates and glycosylation (December 18, 2006), WormBook, ed. The C. elegans Research Community, WormBook, doi/10.1895/ wormbook.1.125.1, http://www.wormbook.org.

Copyright: (C) 2006 Patricia M. Berninsone. This is an open-access article distributed under the terms of the Creative Commons Attribution License, which permits unrestricted use, distribution, and reproduction in any medium, provided the original author and source are credited.

${ }^{\S}$ To whom correspondence should be addressed. E-mail: berninsone@unr.edu
} 


\section{Introduction ${ }^{\dagger}$}

Complex carbohydrates are involved in multiple biological processes, from protein folding, oligomerization and stability, to the immune response and host-pathogen interactions (Varki, 1993). Glycoconjugates also play important roles in developmental processes, as revealed by the pathology of human diseases caused by abnormal glycosylation (Freeze and Aebi, 2005) and genetic studies in model organisms (Haltiwanger and Lowe, 2004).

The structural diversity of naturally occurring glycans is determined by complex biosynthetic pathways, which typically vary among species and appear to be modulated by factors that can differ greatly among cell types. Unlike nucleic acids and proteins, oligosaccharide chains are often assembled in non-linear, branched structures that are synthesized without the use of a template. In principle, each monosaccharide can generate an $\alpha$ or a $\beta$ linkage to one of several positions on another monosaccharide or to another type of molecule, having the potential to produce an astounding molecular complexity. Moreover, individual sugar moieties within a chain can be modified by phosphorylation, sulfation, methylation, O-acetylation, or fatty acylation, further increasing the combinatorial possibilities for oligosaccharide diversity (Varki et al., 1999). In addition to the complexity of glycan moieties per $s e$, it is not possible to predict with certainty whether a protein will be modified by oligosaccharides, even when glycosylation motifs have been observed for a number of glycopeptide bonds (Spiro, 2002). Another source of variation is microheterogeneity, in which the structure of the oligosaccharide attached to each glycosylation site may vary (Jones et al., 2005).The focus of this review will be on the contributions that genetic and biochemical analysis in C. elegans have made to our understanding of the role of glycans in development.

\begin{tabular}{|c|c|}
\hline \multicolumn{2}{|l|}{ Abbreviations: } \\
\hline Cer: & ceramide \\
\hline Fuc: & fucose \\
\hline FucT: & fucosyltransferase \\
\hline GAG: & glycosaminoglycan \\
\hline Gal: & galactose \\
\hline GalNAc: & $\mathrm{N}$-acetylgalactosamine \\
\hline GalNAcT: & $\mathrm{N}$-acetylgalactosiminyltransferase \\
\hline GalT: & galactosyltransferase \\
\hline Glc: & glucose \\
\hline GlcA: & glucuronic acid \\
\hline GlcAT: & glucuronyltransferase \\
\hline GlcNAc: & $\mathrm{N}$-acetylglucosamine \\
\hline GlcT: & glucosyltransferase \\
\hline GnT: & $\mathrm{N}$-acetylglucosamilyltransferase \\
\hline IdoA: & iduronic acid \\
\hline HS: & heparan sulfate \\
\hline HSPG: & heparan sulfate proteoglycan \\
\hline Man: & mannose \\
\hline ManT: & mannosyltransferase \\
\hline PCho: & phosphorylcholine \\
\hline P-glu: & phosphoglucose \\
\hline P-man: & phosphomannose \\
\hline Xyl: & xylose \\
\hline XylT: & xylosyltransferase \\
\hline
\end{tabular}




\section{Glycosylation pathways in C. elegans}

The $C$. elegans genome contains sequences similar to a large number of mammalian genes implicated in the assembly, processing and modification of a variety of glycans (Schachter, 2004; see Appendix 1). Although only a limited number of these genes have been functionally characterized, the degree of homology suggests that $C$. elegans possesses a repertoire of enzymes for the synthesis of a variety of complex carbohydrates. The occurrence of N-glycans [reviewed in Schachter (2004)], GalNAc-O-Ser/Thr glycans (Guerardel et al., 2001), glycosaminoglycans (Toyoda et al., 2000; Yamada et al., 1999), glycolipids (Gerdt et al., 1999; Gerdt et al., 1997) and chitin (Veronico et al., 2001) has been verified in $C$. elegans in structural or biochemical studies. Although $C$. elegans $\mathrm{N}$ - and $\mathrm{O}$-glycans have common features with vertebrate glycans in terms of their core glycan biosynthesis, their terminal structures show significant differences. Among them, C. elegans glycans lack sialic acid (Bacic et al., 1990) and contain unusual fucose additions, O-methylated fucose and mannose and phosphorylcholine substitutions (Cipollo et al., 2002; Haslam and Dell, 2003). In recent years, spectacular progress has been made in developing and refining tools to define the structures of glycans. Our understanding of the role of glycoconjugates in the development of $C$. elegans to date is largely due to the identification of mutations in genes involved in their biosynthesis.

\section{Glycosaminoglycans}

Proteoglycans consist of a core protein and one or more covalently attached glycosaminoglycan (GAG) chains. GAG chains are attached to serine residues in core proteins by a common "tetrasaccharide linkage" region. Structural studies have confirmed that C. elegans synthesizes this ubiquitous linker region (Guerardel et al., 2001). GAGs are linear polysaccharides, composed of repeating disaccharide units consisting of an amino sugar (GlcNAc or GalNAc) and an uronic acid (GlcA and IdoA; see Figure 1). Different classes of GAGs are defined by the composition of the disaccharides: heparan sulfate (HS) has a repeating disaccharide of GlcNAc- $\alpha 1,4-\mathrm{GlcA}-\beta 1,4$, whereas chondroitin and chondroitin sulfate (CS) have GalNAc- $\alpha 1,4-G l c A \beta 1,3$. Monosaccharides within the GAG polymers can be modified in several ways: GlcNAc N-deacetylation and N-sulfation, uronic acid epimerization and $\mathrm{O}$-sulfation at different positions. These modifications result in an enormous molecular complexity that increases the capacity of GAGs to interact with proteins through varied arrangements of sulfated sugar residues (Turnbull et al., 2001). C. elegans produces heparan sulfate containing all modifications previously described in other organisms (Toyoda et al., 2000; Yamada et al., 1999). In contrast, chondroitin appears not to be secondarily modified in $C$. elegans (Toyoda et al., 2000). 


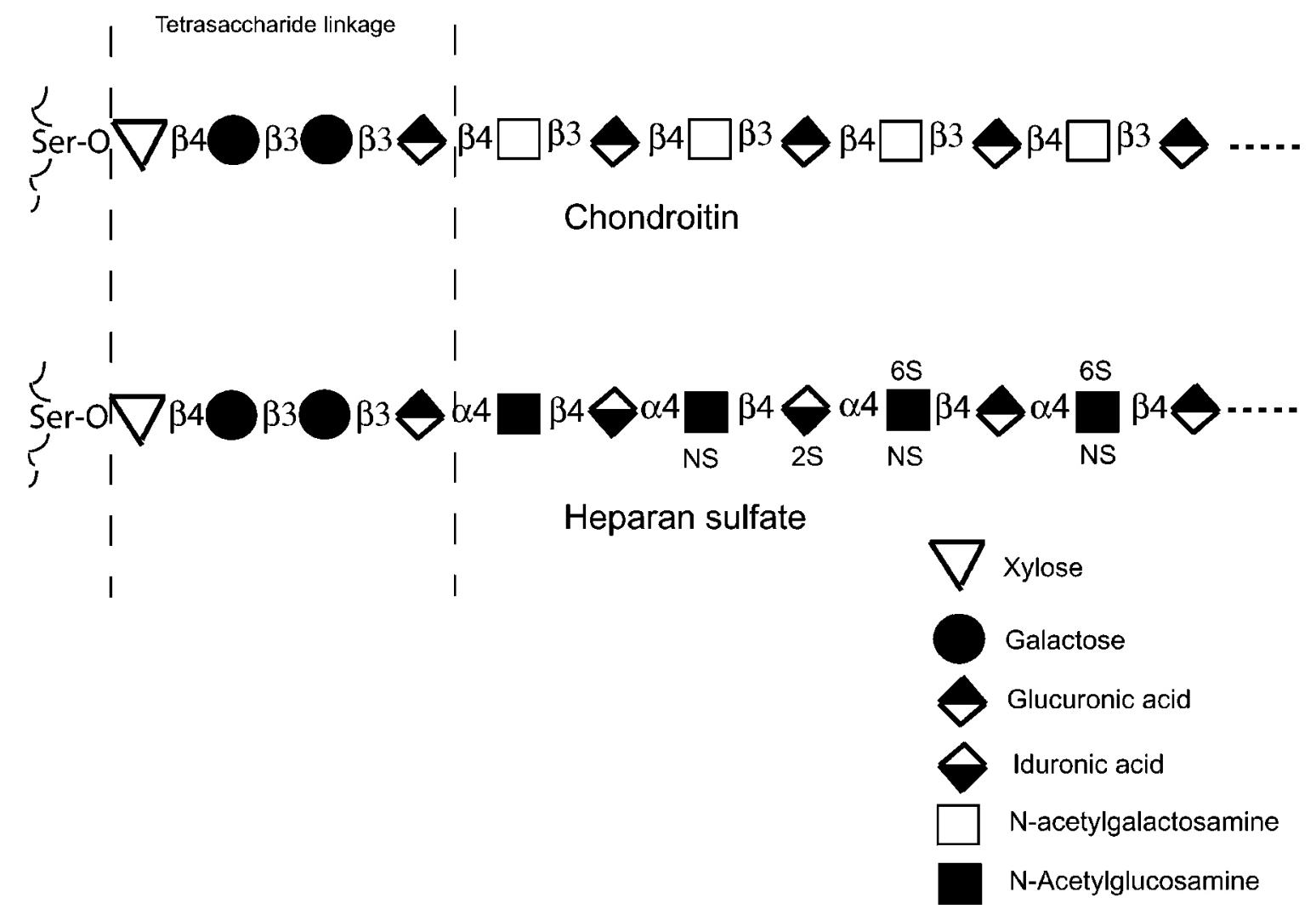

Figure 1. Structure of $\boldsymbol{C}$. elegans chondroitin and heparan sulfate and their linkage tetrasaccharide to proteins. Considerable variations occur in the positions of heparan sulfate sulfations and epimerization (IdoA). [Based on the compositions described in Guerardel et al. (2001); Toyoda et al. (2000); Yamada et al. (1999).]

\subsection{Chondroitin}

A screen for C. elegans mutants defective in vulva morphogenesis identified $8 s q v$ (squashed $\underline{v} u l v a)$ genes (Herman et al., 1999) required for various steps of chondroitin biosynthesis (see Figure 2). With the exception of $s q v-5$, the $s q v$ genes control the biosynthesis of both heparan sulfate and chondroitin (Berninsone et al., 2001; Bulik et al., 2000; Hwang and Horvitz, 2002; Hwang and Horvitz, 2002; Hwang et al., 2003). SQV-5 is a bifunctional glycosyltransferase that functions in the initiation and elongation of chondroitin, but not heparan sulfate chains (Hwang et al., 2003; Mizuguchi et al., 2003), suggesting that defects in the biosynthesis of chondroitin account for the defects caused by mutations in all $s q v$ genes.

In all the sqv mutants, the vulval extracellular space fails to expand during vulval morphogenesis (Herman et al., 1999). Strong sqv mutations also cause maternal-effect lethality: most progeny of homozygous mutants fail to initiate cytokinesis. These mutant eggs fail to form the fluid-filled extracellular space between the egg and the eggshell (Herman and Horvitz, 1999; Hwang and Horvitz, 2002). The ability of extracellular chondroitin to interact with water and generate osmotic pressure might be implicated in the expansion of the extracellular spaces in the $C$. elegans embryo and vulva; among other possibilities (Hwang et al., 2003).

\subsection{Heparan sulfate}

The EXT gene family members are glycosyltransferases required for the biosynthesis of heparan sulfate chains. Mutations in EXT1 and EXT2 lead to hereditary multiple exostoses. Only two homologs of the EXT family exist in C. elegans: rib-1 and rib-2. rib-2 is essential for embryonic development (Morio et al., 2003) and encodes a unique $\alpha 1,4-\mathrm{N}$-acetylglucosaminyltransferase involved in both the biosynthetic initiation and elongation of heparan sulfate (Kitagawa et al., 2001). The biochemical activity of RIB-1 remains elusive. 


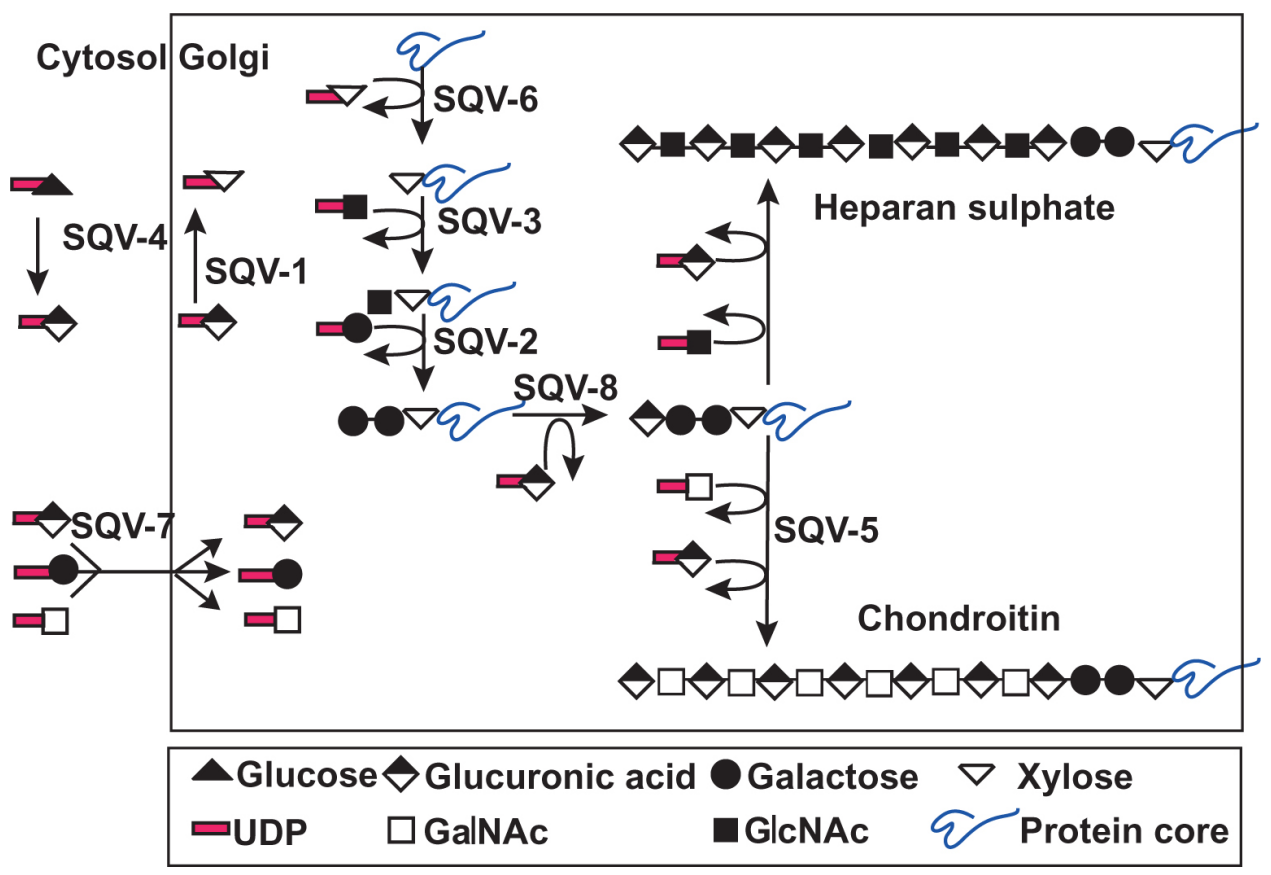

Figure 2. Model of the function of the SQV proteins in the biosynthesis of heparan and chondroitin chains. SQV-4 (UDP-glucose dehydrogenase) synthesizes UDP-glucuronic acid (Hwang and Horvitz, 2002) and SQV-1 catalyzes the synthesis of UDP-xylose by decarboxylation of UDP-glucuronic acid (Hwang and Horvitz, 2002). SQV-7 transports UDP-glucuronic acid, UDP-galactose and UDP-N-acetylgalactosamine into the Golgi lumen (Berninsone et al., 2001). sqv-6, $s q v-3, s q v-2$ and $s q v-8$ encode the xylosyltransferase, galactosyltransferase I, galactosyltransferase II and glucuronyltransferase I, respectively, involved in the synthesis of the common "core tetrasaccharide" linkage region (Bulik et al., 2000; Herman and Horvitz, 1999; Hwang et al., 2003). SQV-5 is required for the polymerization of chondroitin chains (Hwang et al., 2003; Mizuguchi et al., 2003). Reprinted by permission from Macmillan Publishers Ltd: Nature 423, 439-443, copyright (2003).

Contrasting with the essential nature of heparan sulfate chain synthesis (Morio et al., 2003), C. elegans mutants lacking three heparan sulfate modifying enzymes are viable and fertile. hse-5, hst-6 and hst-2 mutants (HSE-5: glucuronyl C5-epimerase, HST-6: heparan sulfate 6O-sulfotransferase and HST-2: 2O-sulfotransferase) exhibit distinct as well as overlapping axonal and cellular guidance defects in specific neurons (Bulow and Hobert, 2004). hst-2 mutants also display cell migration defects (Kinnunen et al., 2005). These HS modifications are required for the function of the slt-1/sax-3 signaling system in some, but not all cellular contexts (Bulow and Hobert, 2004).

Defects in heparan sulfate synthesis or specific modifications disrupt neuroblast migrations. C-5 epimerized and 6-O-sulfated heparan sulfate chains attached to the cell surface proteoglycans syndecan (SDN-1) and glypican (GPN-1) are required for the activity of KAL-1, the C. elegans anosmin ortholog, in embryonic neuroblast migration (Hudson et al., 2006). These in vivo analyses underscore the importance of molecular diversity encoded by HS chains and argue that each individual modification provides information required for axon patterning and cell migration.

\subsection{Heparan sulfate and chondroitin modified proteins}

The C. elegans genome encodes several putative heparan sulfate proteoglycan (HSPG) core proteins: the cell surface HSPGs SDN-1/syndecan (Minniti et al., 2004; Rhiner et al., 2005) and GPN-1/glypican (Hudson et al., 2006) and the basement membrane HSPGs UNC-52/perlecan (Rogalski et al., 1993) and CLE-1/collagen XVIII (Ackley et al., 2001). SDN-1 (Minniti et al., 2004) and GPN-1 (Hudson et al., 2006) have been shown to be modified by heparan sulfate chains.

Nine chondroitin proteoglycan core proteins (CPG-1 to CPG-9) were identified in C. elegans using a combination of biochemical purification and mass spectrometry (Olson et al., 2006). None of these proteins have homologs in vertebrates or other invertebrates, but all of them have sequence motifs required for initiation of glycosaminoglycan biosynthesis similar to those found in vertebrates. Simultaneous RNAi depletion of two of these core proteins (CPG-1/C07G2.1a and CPG-2/B0280.5) resulted in multinucleate single cell embryos (Olson et al., 2006), resembling the embryonic phenotype resulting from inhibiting the SQV-5 chondroitin synthase (Hwang et 
al., 2003; Mizuguchi et al., 2003). This study shows that the chondroitin proteoglycans encoded by cpg-1 and cpg-2 play a crucial role in embryonic cytokinesis.

\section{N-linked glycans}

$\mathrm{N}$-linked glycans are complex and diverse sugar chains attached to an asparagine residue of a polypeptide chain within the consensus peptide sequence Asn-X-Ser/Thr. The yeast and mammalian biosynthetic pathways have been elucidated in great detail (Herscovics, 1999; Kornfeld and Kornfeld, 1985). The initial steps of this pathway are conserved in most eukaryotes and involve the synthesis of a lipid-linked oligosaccharide precursor structure that is transferred en bloc to nascent proteins in the ER. Transfer of $\mathrm{Glc}_{3} \mathrm{Man}_{9} \mathrm{GlcNAc}_{2}$ to Asn is followed by glucose trimming in the ER. Subsequent cycles of glucose re-addition and removal participate in quality control of protein-folding. The processed high-mannose $\mathrm{Man}_{5} \mathrm{GlcNAc}_{2}$-Asn N-glycan serves as a substrate for the diversification of N-glycans in the Golgi. In vertebrates, these reactions generate a large repertoire of hybrid and complex N-glycan subtypes (see Figure 3, top panel).

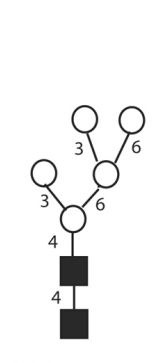

High mannose

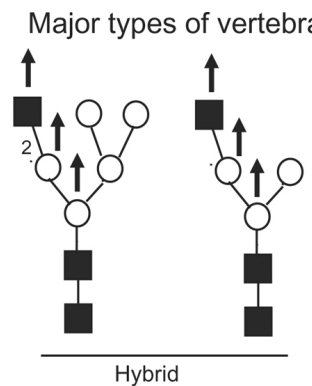

Hybrid
Representative C.elegans N-glycans

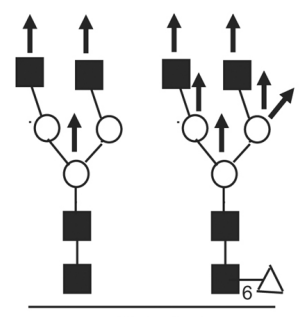

Complex
PC : phosphorylcholine

$\mathrm{N}$-acetylglucosamine

Mannose

$\triangle$ Fucose

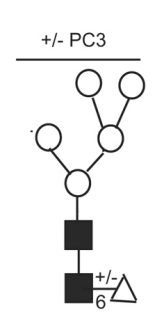

High mannose

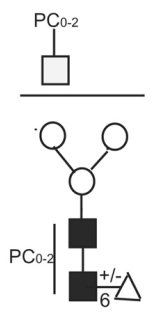

Pauci-mannose

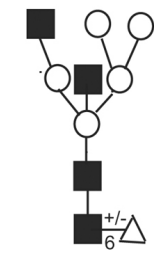

Hybrid type

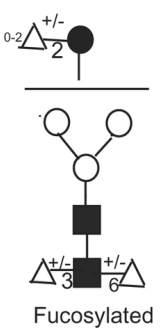

Galactose

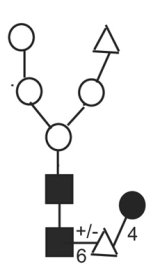

Figure 3. Comparative overview of the major types of vertebrate $\mathrm{N}$-glycan subtypes and some representative $C$. elegans $\mathrm{N}$-glycans. Top panel: Vertebrate diversification in the Golgi apparatus generates high-mannose, hybrid and complex N-glycan subtypes. Most cell surface and secreted $\mathrm{N}$-glycans are of the complex subtype. Vertical arrows indicate locations of branch formation in diversification, not all of which occur on a single N-glycan. (Adapted from (Varki et al., 1999) Bottom panel: The main classes of C. elegans N-glycans include high-mannose (up to Man9GlcNAc2), pauci-mannosidic and hybrid type. Note that this scheme only includes some of the documented structures.

\subsection{Diversity of $\mathrm{N}$-glycan structures in C. elegans}

Whereas the N-glycan biosynthetic pathway appears to be fairly well conserved in C. elegans (see Appendix 1), the resulting $\mathrm{N}$-glycan structures are qualitatively and quantitatively different than those found in mammals, as shown by structural analysis of N-glycans enzymatically released from C. elegans glycoproteins (see Figure 3, reviewed in Haslam and Dell, 2003; Schachter, 2004). C. elegans predominantly contains oligomannose $\mathrm{Man}_{5-9} \mathrm{GlcNAc}_{2}$-Asn glycans (which are present in vertebrates) and large amounts of paucimannose $\mathrm{Man}_{3-4} \mathrm{GlcNAc}_{2}$-Asn glycans (which are not usually present in vertebrates; Altmann et al., 2001; Cipollo et al., 2002; Haslam and Dell, 2003; Haslam et al., 2002; Natsuka et al., 2002; Schachter et al., 2002; Zhang et al., 2003; see Figure 3, bottom panel). Complex and hybrid N-glycans, which are very abundant in vertebrates, are either absent or present in low levels in C. elegans (Cipollo et al., 2002; Haslam et al., 2002; Natsuka et al., 2002), although this organism has at least some of the biosynthetic components required for the synthesis of high mannose and abbreviated mammalian-type complex glycans. GnTI (N-acetylglucosaminyltransferase I) initiates and is essential for the conversion of $\mathrm{Man}_{5} \mathrm{GlcNAc}_{2}$-Asn to hybrid and complex N-glycans. Three genes encoding enzymatically active GnTI (gly-12, gly-13 and gly-14) exist in C. elegans (Chen et al., 1999). GnTII (gly-20; Chen et al., 2002) and 
GnTV (gly-2; Warren et al., 2002; Warren et al., 2002), which initiate the formation of the N-glycan "antennae", are also expressed in $C$. elegans. A model to explain this apparent discrepancy has been proposed, based on the expression in C. elegans of a N-acetylglucosaminidase, which removes GnTI-added GlcNAc, thus preventing the formation of complex glycan and resulting in the formation of large amounts of "paucimannose" N-glycans (Zhang et al., 2003).

Unusually modified N-glycans have been detected in C. elegans. Fuc-rich glycans, which carry terminal Fuc on the antennae as well as the core, sometimes contain O-methylated Fuc and O-methylated Man. Phosphorylcholine (PCho)-substituted N-glycans have been identified in a high mannose structure carrying three PCho groups (Cipollo et al., 2002) and on complex type glycans where PCho is attached at GlcNAc (Haslam and Dell, 2003). This last structure has been previously found in several parasitic nematodes (Haslam et al., 1999; Haslam et al., 1997; Morelle et al., 2000).

The structural studies summarized above identified N-glycans extracted from mixed stage C. elegans cultures. These preparations are expected to be enriched in glycans from the largest and most represented developmental stages. A recent study (Cipollo et al., 2005) has shown that the N-glycan profile of each developmental stage appears to be unique. The general trend of the number and abundance of $\mathrm{N}$-glycans was Dauer L1>Adult $\sim$ L4>L3 L2. Dauer larvae contain complex glycans with higher molecular masses than those of other stages, and a higher abundance of high molecular weight PCho-containing glycans was observed in L1 and Dauer larvae. This study also documents the structures of novel N-glycans, e.g., difucosyl PCho glycans in which PCho substitutes both core and terminally linked GlcNAc.

\subsection{N-glycosylated proteins in C. elegans}

The rather strict consensus peptide sequence Asn-X-Ser/Thr for N-glycosylation has been supported by numerous structural, mutagenic and in vitro approaches (Spiro, 2002). Although this sequence occurs frequently in proteins, N-linked glycosylation does not occur at every potential glycosylation site, most probably due to conformational factors (Apweiler et al., 1999). Thus, it is not possible to predict with certainty if a protein is in fact $\mathrm{N}$-glycosylated. Microheterogeneity in N-glycan chains can also occur among different molecules of the same protein (Jones et al., 2005).

Recently developed methods have allowed the identification of 304 C. elegans proteins containing N-glycans and the simultaneous determination of the glycosylation sites (Fan et al., 2004; Fan et al., 2005; Kaji et al., 2003). These studies employed lectin affinity chromatography to isolate glycopeptides generated by tryptic digestion of $C$. elegans protein fractions, followed by a variety of mass spectrometry approaches. All but four of the $\mathrm{N}$-glycosylation sites identified correspond to the conventional Asn-X-Ser/Thr. Three peptides contain Asn-X-Cys (Fan et al., 2005; Kaji et al., 2003). The identified N-glycoproteins comprise soluble and hydrophobic proteins, and many of them are extracellular matrix components which have been implicated in cell adhesion or are components of basement membranes. Among them, PAT-2, INA-1 (the two C. elegans integrin $\alpha$ subunits), PAT-3 (the integrin $\beta$ subunit), T22A3.8, EPI-1, LAM-1, C54D1.5 (the four laminin subunit gene products), NID-1 (nidogen) and DGN-1 (dystroglycan) contain at least one N-linked glycan [see Fan et al. (2005); Kaji et al., (2003) for complete lists].

In individual studies, some $C$. elegans proteins have been demonstrated to contain $\mathrm{N}$-linked oligosaccharides. GLP-1, a member of the LIN-12/Notch family of receptor proteins essential for distal tip cell (DTC) control of germline proliferation (Austin and Kimble, 1987) is a glycoprotein (Crittenden et al., 1994).

MIG-17, a member of the ADAM (a disintegrin and metalloprotease) family, regulates directional migration of the distal tip cell (DTC) (Nishiwaki et al., 2000). Sensitivity to N-glycanase indicated that MIG-17 is $\mathrm{N}$-glycosylated (Nishiwaki et al., 2004). A mutation in mig-23 causes defective DTC migration and genetically interacts with mig-17. MIG-23 is a membrane-bound nucleoside diphosphatase (NDPase) required for glycosylation and proper localization of MIG-17 (Nishiwaki et al., 2004). NDPase activities in the lumen of the Golgi apparatus generate nucleoside monophosphates required for translocation of nucleotide sugars from the cytosol into the Golgi lumen (Berninsone et al., 1994). Nucleotide sugars are the activated donors for glycosylation reactions in the lumen of the endoplasmic reticulum and Golgi apparatus (Hirschberg et al., 1998). Genetic studies in S.cerevisiae showed that guanosine diphosphatase, an NDPase, is required for protein and sphingolipid glycosylation in the Golgi lumen (Abeijon et al., 1993). Hence, MIG-23 likely affects DTC migration through its role in the transport of nucleotide sugars into the lumen of the Golgi apparatus. Although the mig-23 mutation may affect the glycosylation of other proteins, MIG-23 appears to regulate DTC migration through glycosylation and correct localization of MIG-17. 


\section{O-linked glycans}

\subsection{O-GalNAc linked (mucin-type) glycans}

The GalNAc $\alpha$-Ser/Thr linkage has been considered a hallmark of mucins where it occurs in clusters. However, this linkage has also been found in a wide variety of other proteins (Hang and Bertozzi, 2005). No primary amino acid consensus sequence has emerged for mucin-type O-linked glycosylation. In general, glycosylation of Thr is preferred over Ser (Elhammer et al., 1993) and the linkage is found in clusters of Ser/Thr residues with a Bturn near Pro and at a distance from charged amino acids (Hang and Bertozzi, 2005).

C. elegans expresses a family of functional polypeptide $\mathrm{N}$-acetylgalactosaminyltransferases (ppGalNacT) involved in the initiation of mucin-type O-glycosylation (Hagen and Nehrke, 1998; see Appendix 1). A C. elegans core $1 \beta 3-G a l T$ or T-synthase has been recently characterized (Ju et al., 2006). This enzyme adds Gal to GalNAc $\alpha 1-S e r / T h r$ to generate the core 1 structure Gal $\beta 1-3$ GalNAc $\alpha 1-S e r / T h r$. This is the most common of $\mathrm{O}$-glycan structures in vertebrates and is a precursor to more complex O-glycans. Two families of unusual mucin-type O-glycans were identified in C. elegans (Guerardel et al., 2001). Both families were characterized by the presence of multiple $\beta$-Glc residues in non-reducing terminal positions, a type of substitution without precedent in O-glycans. One of these families presented either type- 1 core Gal $\beta 1,3 \mathrm{GalNAc}$ or one of three novel core types: Gal $\beta 1,6[\mathrm{Gal} \beta 1,3] \mathrm{GalNAc}$ Glc $\beta 1-6[\mathrm{Gal} \beta 1,3] \mathrm{GalNAc}$ and [Glc $\beta 1-6(\mathrm{Glc} \beta 1,4) \mathrm{Gal} \beta 1-3)] \mathrm{GalNAc}$. Some of the O-glycans contain the GlcA $\beta 1,3$ Gal $\beta 1,3$ GalNAc trisaccharide sequence. The second mucin type O-glycan characterized is unusual in that it presented a GlcNAc-ol in the terminal position. This suggests that it would be linked to the protein through a GlcNAc and not a GalNAc. The unusual features of these structures suggest the expression in $C$. elegans of novel glycosyltransferase activities. For example, a novel $\beta 1,6 \mathrm{GlcT}$ acting on the GalNAc residue of the core has been cloned and expressed (Warren et al., 2002). The enzyme is encoded by the gly-1 gene and is homologous to the vertebrate $\beta 1,6 \mathrm{GINAcT}$ that acts on the GalNAc residue of O-glycan core 1 (Galß1,3GlcNAc) to make O-glycan core 2.

The large amounts of O-glycans purified in this study suggest that $C$. elegans expresses an abundance of highly O-glycosylated proteins. Studies on the parasitic nematode Toxocara canis have shown that it secretes a family of highly O-glycosylated mucin type glycoproteins (Loukas et al., 2000; Dell et al., 1999; Khoo et al., 1991). In C. elegans, let-653 encodes a mucin-type glycoprotein (Jones and Baillie, 1995). Mutations in let-653 result in larval death and vacuole formation anterior to the pharyngeal bulb, suggesting malfunction or deformation of the excretory/secretory apparatus. Biochemical characterization of a C. elegans L1-specific surface antigen suggested that it contains O-linked carbohydrates (Hemmer et al., 1991). This antigen is not detected on the surface of L1 animals carrying mutations in the $s r f-3$ gene, which encodes a Golgi UDP-Gal/UDP-GlcNAc transporter implicated in glycosylation of surface components (Hoflich et al., 2004). Loss of SRF-3 activity affects both N-linked and O-linked glycosylation (Cipollo et al., 2004).

\subsection{O-GIcNAc linked}

O-linked GlcNAc at Ser and Thr residues is an evolutionary conserved modification emerging as a key regulator of nuclear and cytoplasmic protein activity (Love and Hanover, 2005). The GlcNAc transferase (OGT) responsible for this modification was the first glycopeptide-forming enzyme to be localized outside the secretory apparatus (Lubas et al., 1997). O-GlcNAc addition may compete with O-phosphorylation for certain Ser/Thr target sites, suggesting a potential regulatory cycle in which cytosolic $\beta$-N-acetylglucosaminidase plays a key role (Comer and Hart, 2001). O-GlcNAc addition is driven in part by the levels of UDP-GlcNAc derived from the hexosamine biosynthetic pathway, a nutrient-sensing pathway implicated in cellular signaling (Hanover, 2001). In mammals, the OGT gene is essential for embryonic and stem cell development and produces multiple transcripts (Hanover et al., 2003; O'Donnell et al., 2004; Shafi et al., 2000). O-GlcNAc addition has been implicated in mammalian insulin resistance (Hanover, 2001; McClain et al., 2002; Vosseller et al., 2002; Wells et al., 2001) histone remodeling, transcription, proliferation, apoptosis and proteosomal degradation.

In C. elegans, ogt-1 and oga-1 encode the single orthologs of OGT (Lubas et al., 1997) and O-GlcNAcase (Forsythe et al., 2006), respectively. Putative null alleles of ogt-1 and oga-l are viable and fertile, allowing the examination of the role of O-GlcNAc in this organism. Nuclear pore complexes in the ogt-1 mutant strain lack O-GlcNAc but are capable of transporting transcription factors into the nucleus at normal rates. Conversely, oga-1 null mutants accumulate O-GlcNAc on nuclear pores and other proteins. A dramatic elevation in the levels of trehalose and glycogen was detected in ogt- 1 and $o g a-1$ mutants with a concomitant decrease in triglyceride storage (Hanover et al., 2005). The ogt-1 deletion allele suppresses dauer formation induced by the partial loss of daf-2, 
encoding an insulin-like receptor (Riddle, 1977). In comparable conditions, the oga- 1 null mutant enhances dauer formation of the daf-2 mutant. Thus, the nematode hexosamine-signaling pathway interacts with the insulin-like-signaling pathway, as suggested in mammals. The insulin-like-signaling pathway modulates lipid and carbohydrate storage in C. elegans (Kimura et al., 1997). These studies implicate O-GlcNAc cycling by OGT-1 and OGA-1 in modulating insulin-like signaling and/or parallel pathways regulating dauer formation in C. elegans.

\section{Glycolipids}

A glycosphingolipid consists of an oligosaccharide usually attached via glucose or galactose to the terminal primary hydroxyl group of the lipid moiety ceramide. Most mammalian glycosphingolipids contain a Gal- $\beta 1$,4-Glc- $\beta 1$-ceramide core, which is extended by the stepwise addition of further monosaccharides giving rise to several defined core structures (Varki et al., 1999).

C. elegans glycosphingolipids belong to the invertebrate-specific arthro-series, which contain the invertebrate-specific Man- $\beta 1,4-G l c-\beta 1$-ceramide core, extended by addition of neutral sugars. They share structural homology with the equivalent structures from the porcine parasitic nematode, Ascaris suum (Gerdt et al., 1997; Gerdt et al., 1999; Lochnit et al., 1997). Some of these glycosphingolipids are modified by phosphorylcholine (PCho), an antigenic determinant frequently detected in parasitic nematodes (Lochnit et al., 1998; Maizels et al., 1987).

A role for glycosphingolipids as receptors for the Bacillus thuringensis $(\mathrm{Bt})$ crystal toxin was revealed by genetic studies in C. elegans. The crystal (Cry) proteins produced by Bt are pore forming toxins that are lethal to insects and nematodes but generally innocuous to vertebrates. The potential problem associated with long-term use of transgenic crops expressing Cry proteins to control insect pests is the development of resistance among target populations. Mutations in the bre ( $\underline{B} t \underline{\text { resistant}) ~ g e n e s ~ c a u s e ~ B t ~ r e s i s t a n c e ~ i n ~ C . ~ e l e g a n s ~(G r i f f i t t s ~ e t ~ a l ., ~ 2003 ; ~}$ Griffitts et al., 2001; Marroquin et al., 2000). The bre genes encode four glycosyltransferases that act in a single pathway and are required for the uptake of toxin into intestinal cells. (Griffitts et al., 2003; Griffitts et al., 2001). BRE-2 and BRE-4 synthesize the Gal $\beta 1,3 \mathrm{GlcNAc}$ and GalNAc $\beta 1,4 \mathrm{GlcNAc}$ moieties, respectively, which are commonly found on glycolipids and glycoproteins. bre-3 and bre-5 are the C. elegans homologs of the Drosophila genes egghead and brainiac, respectively, which encode consecutive glycosyltransferases involved in the synthesis of the carbohydrate chains on glycosphingolipids (Griffitts et al., 2003). Lipid and glycoprotein analysis of bre mutant animals demonstrated that the BRE enzymes are required to synthesize the carbohydrate chains of glycolipids and that Bt toxin specifically binds glycolipids (Griffitts et al., 2005).

Mutations in bre-5 and other genes involved in glycosphingolipid biosynthesis also suppress the egg-laying defect associated with elevated lin-12 activity (Katic et al., 2005). Brainiac modulates Notch signaling in Drosophila (Goode et al., 1996; Goode and Perrimon, 1997) suggesting that the importance of glycosphingolipids for proper LIN-12/Notch signaling might be functionally conserved. Genetic evidence suggests that bre-5 functions prior to LIN-12 activation by ligand-induced ectodomain shedding (Katic et al., 2005).

\section{Chitin}

Chitin, a linear polymer of $\beta 1,4$ linked GlcNAc, is one of the main components of the fungal cell wall and the exoskeletons of arthropods. The eggshells of many free-living and parasitic nematodes contain chitin (Brydon et al., 1987; Wharton, 1980). In addition, this polysaccharide has been detected in the feeding apparatus of the strongyloid nematode Oesophagostomum dentatun (Neuhaus et al., 1997). In C. elegans, chitin is detected in the eggshell and in elaborate patterns in the pharyngeal lumen walls of adult and larvae (Zhang et al., 2005). Two genes encoding chitin synthases, $c h s-1$ and $c h s-2$, exhibit different temporal expression patterns: $c h s-1$ is expressed in later larval stages and adults, while chs-2 expression is restricted to a short period before each molt, but not in adults (Veronico et al., 2001). Maternal chs-1 gene activity is likely involved in the production of eggshell chitin, as shown by RNAi experiments and analysis of $c h s-1$ null mutants. $c h s-2$ is expressed in the pharynx and inactivation of $c h s-2$ by RNAi revealed visible defects in the grinder (Zhang et al., 2005). Hence, chs- 1 and chs- 2 play different and non-overlapping roles in development.

\section{Conclusions}

Assignment of biological functions to glycans and glycan modified acceptors in any multicellular organism is a difficult task. The extreme complexity of glycan structures is compounded by the fact that many yet unidentified 
acceptors might be modified by the same type of glycan. In addition, very little is known about how the expression of these molecules is regulated during development and differentiation. C. elegans and small model organisms are likely to provide platforms where perturbations of glycan structure can be analyzed in the context of development and differentiation. Sensitive techniques for glycan analysis can be applied to mutants to obtain qualitative and quantitative information about their glycosylation phenotypes. Identification of the specific acceptor(s) carrying the abnormal glycan structures represents an additional challenge, yet these studies may help understand the molecular mechanisms linking glycosylation defects with specific phenotypes. Despite the enormous difference in complexity with mammals, the recent genetic and structural studies suggest that $C$. elegans is a promising model system for investigating basic roles of glycans in development.

\section{References}

Abeijon, C., Yanagisawa, K., Mandon, E.C., Hausler, A., Moremen, K., Hirschberg, C.B., and Robbins, P.W. (1993). Guanosine diphosphatase is required for protein and sphingolipid glycosylation in the Golgi lumen of Saccharomyces cerevisiae. J. Cell Biol. 122, 307-323. Abstract Article

Ackley, B.D., Crew, J.R., Elamaa, H., Pihlajaniemi, T., Kuo, C.J., and Kramer, J.M. (2001). The NC1/endostatin domain of Caenorhabditis elegans type XVIII collagen affects cell migration and axon guidance. J. Cell Biol. 152, 1219-1232. Abstract Article

Altmann, F., Fabini, G., Ahorn, H., and Wilson, I.B. (2001). Genetic model organisms in the study of N-glycans. Biochimie 83, 703-712. Abstract Article

Apweiler, R., Hermjakob, H., and Sharon, N. (1999). On the frequency of protein glycosylation, as deduced from analysis of the SWISS-PROT database. Biochim. Biophys. Acta 1473, 4-8. Abstract

Austin, J., and Kimble, J. (1987). glp- 1 is required in the germ line for regulation of the decision between mitosis and meiosis in C. elegans. Cell 51, 589-599. Abstract Article

Bacic, A., Kahane, I., and Zuckerman, B.M. (1990). Panagrellus redivivus and Caenorhabditis elegans: evidence for the absence of sialic acids. Exp. Parasitol. 71, 483-488. Abstract Article

Berninsone, P., Hwang, H.Y., Zemtseva, I., Horvitz, H.R., and Hirschberg, C.B. (2001). SQV-7, a protein involved in Caenorhabditis elegans epithelial invagination and early embryogenesis, transports UDP-glucuronic acid, UDP-N-acetylgalactosamine, and UDP-galactose. Proc. Natl. Acad. Sci. U.S.A. 98, 3738-3743. Abstract Article

Berninsone, P., Miret, J.J., and Hirschberg, C.B. (1994). The Golgi guanosine diphosphatase is required for transport of GDP-mannose into the lumen of Saccharomyces cerevisiae Golgi vesicles. J. Biol. Chem. 269, 207-211. Abstract

Brydon, L.J., Gooday, G.W., Chappell, L.H., and King, T.P. (1987). Chitin in egg shells of Onchocerca gibsoni and Onchocerca volvulus. Mol. Biochem. Parasitol. 25, 267-272. Abstract Article

Bulik, D.A., Wei, G., Toyoda, H., Kinoshita-Toyoda, A., Waldrip, W.R., Esko, J.D., Robbins, P.W., and Selleck, S.B. (2000). sqv-3, -7, and -8, a set of genes affecting morphogenesis in Caenorhabditis elegans, encode enzymes required for glycosaminoglycan biosynthesis. Proc. Natl. Acad. Sci. U.S.A. 97, 10838-10843. Abstract Article

Bulow, H.E., and Hobert, O. (2004). Differential sulfations and epimerization define heparan sulfate specificity in nervous system development. Neuron 41, 723-736. Abstract Article

Caffaro, C.E., Hirschberg, C.B., and Berninsone, P. (2006). The independent and simultaneous translocation of two substrates by a nucleotide sugar transporter. Proc. Natl. Acad. Sci. U.S.A. 103, 16176-16181. Article

Chen, S., Tan, J., Reinhold, V.N., Spence, A.M., and Schachter, H. (2002). UDP-N-acetylglucosamine: alpha-3-D-mannoside beta-1,2-N-acetylglucosaminyltransferase I and UDP-N-acetylglucosamine:alpha-6-Dmannoside beta-1,2-N-acetylglucosaminyltransferase II in Caenorhabditis elegans. Biochim. Biophys. Acta 1573, 271-279. Abstract

Chen, S., Zhou, S., Sarkar, M., Spence, A.M., and Schachter, H. (1999). Expression of three Caenorhabditis elegans $\mathrm{N}$-acetylglucosaminyltransferase I genes during development. J. Biol. Chem. 274, 288-297. Abstract Article 
Cipollo, J.F., Awad, A.M., Costello, C.E., and Hirschberg, C.B. (2004). srf-3, a mutant of Caenorhabditis elegans, resistant to bacterial infection and to biofilm binding, is deficient in glycoconjugates. J. Biol. Chem. 279, 52893-52903. Abstract Article

Cipollo, J.F., Awad, A.M., Costello, C.E., and Hirschberg, C.B. (2005). N-Glycans of Caenorhabditis elegans are specific to developmental stages. J. Biol. Chem. 280, 26063-26072. Abstract Article

Cipollo, J.F., Costello, C.E., and Hirschberg, C.B. (2002). The fine structure of Caenorhabditis elegans N-glycans. J. Biol. Chem. 277, 49143-49157. Abstract Article

Comer, F.I., and Hart, G.W. (2001). Reciprocity between O-GlcNAc and O-phosphate on the carboxyl terminal domain of RNA polymerase II. Biochemistry 40, 7845-7852. Abstract Article

Crittenden, S.L., Troemel, E.R., Evans, T.C., and Kimble, J. (1994). GLP-1 is localized to the mitotic region of the C. elegans germ line. Development 120, 2901-2911. Abstract

Dell, A., Haslam, S.M., Morris, H.R., and Khoo, K.H. (1999). Immunogenic glycoconjugates implicated in parasitic nematode diseases. Biochim. Biophys. Acta 1455, 353-362. Abstract

Elhammer, A.P., Poorman, R.A., Brown, E., Maggiora, L.L., Hoogerheide, J.G., and Kezdy, F.J. (1993). The specificity of UDP-GalNAc:polypeptide N-acetylgalactosaminyltransferase as inferred from a database of in vivo substrates and from the in vitro glycosylation of proteins and peptides. J. Biol. Chem. 268, 10029-10038. Abstract

Fan, X., She, Y.M., Bagshaw, R.D., Callahan, J.W., Schachter, H., and Mahuran, D.J. (2004). A method for proteomic identification of membrane-bound proteins containing Asn-linked oligosaccharides. Anal. Biochem. 332, 178-186. Abstract Article

Fan, X., She, Y.M., Bagshaw, R.D., Callahan, J.W., Schachter, H., and Mahuran, D.J. (2005). Identification of the hydrophobic glycoproteins of Caenorhabditis elegans. Glycobiology 15, 952-964. Abstract Article

Forsythe, M.E., Love, D.C., Lazarus, B.D., Kim, E.J., Prinz, W.A., Ashwell, G., Krause, M.W., and Hanover, J.A. (2006). Caenorhabditis elegans ortholog of a diabetes susceptibility locus: oga-1 (O-GlcNAcase) knockout impacts O-GlcNAc cycling, metabolism, and dauer. Proc. Natl. Acad. Sci. U.S.A. 103, 11952-11957. Abstract Article

Freeze, H.H., and Aebi, M. (2005). Altered glycan structures: the molecular basis of congenital disorders of glycosylation. Curr. Opin. Struct. Biol. 15, 490-498. Abstract Article

Gerdt, S., Dennis, R.D., Borgonie, G., Schnabel, R., and Geyer, R. (1999). Isolation, characterization and immunolocalization of phosphorylcholine-substituted glycolipids in developmental stages of Caenorhabditis elegans. Eur. J. Biochem. 266, 952-963. Abstract Article

Gerdt, S., Lochnit, G., Dennis, R.D., and Geyer, R. (1997). Isolation and structural analysis of three neutral glycosphingolipids from a mixed population of Caenorhabditis elegans (Nematoda:Rhabditida). Glycobiology 7, 265-275. Abstract

Goode, S., Morgan, M., Liang, Y.P., and Mahowald, A.P. (1996). Brainiac encodes a novel, putative secreted protein that cooperates with Grk TGF alpha in the genesis of the follicular epithelium. Dev. Biol. 178, 35-50. Abstract Article

Goode, S., and Perrimon, N. (1997). Brainiac and fringe are similar pioneer proteins that impart specificity to notch signaling during Drosophila development. Cold Spring Harb. Symp. Quant. Biol. 62, 177-184. Abstract

Griffitts, J.S., Haslam, S.M., Yang, T., Garczynski, S.F., Mulloy, B., Morris, H., Cremer, P.S., Dell, A., Adang, M.J., and Aroian, R.V. (2005). Glycolipids as receptors for Bacillus thuringiensis crystal toxin. Science 307, 922-925. Abstract Article

Griffitts, J.S., Huffman, D.L., Whitacre, J.L., Barrows, B.D., Marroquin, L.D., Muller, R., Brown, J.R., Hennet, T., Esko, J.D., and Aroian, R.V. (2003). Resistance to a bacterial toxin is mediated by removal of a conserved glycosylation pathway required for toxin-host interactions. J. Biol. Chem. 278, 45594-45602. Abstract Article 
Griffitts, J.S., Whitacre, J.L., Stevens, D.E., and Aroian, R.V. (2001). Bt toxin resistance from loss of a putative carbohydrate-modifying enzyme. Science 293, 860-864. Abstract Article

Guerardel, Y., Balanzino, L., Maes, E., Leroy, Y., Coddeville, B., Oriol, R., and Strecker, G. (2001). The nematode Caenorhabditis elegans synthesizes unusual O-linked glycans: identification of glucose-substituted mucin-type O-glycans and short chondroitin-like oligosaccharides. Biochem. J. 357, 167-182. Abstract Article

Hagen, F.K., and Nehrke, K. (1998). cDNA cloning and expression of a family of UDP-N-acetyl-Dgalactosamine:polypeptide $\mathrm{N}$-acetylgalactosaminyltransferase sequence homologs from Caenorhabditis elegans. J. Biol. Chem. 273, 8268-8277. Abstract Article

Haltiwanger, R.S., and Lowe, J.B. (2004). Role of glycosylation in development. Annu. Rev. Biochem. 73, 491-537. Abstract Article

Hang, H.C., and Bertozzi, C.R. (2005). The chemistry and biology of mucin-type O-linked glycosylation. Bioorg. Med. Chem. 13, 5021-5034. Abstract Article

Hanover, J.A. (2001). Glycan-dependent signaling: O-linked N-acetylglucosamine. FASEB J. 15, 1865-1876. Abstract Article

Hanover, J.A., Forsythe, M.E., Hennessey, P.T., Brodigan, T.M., Love, D.C., Ashwell, G., and Krause, M. (2005). A Caenorhabditis elegans model of insulin resistance: altered macronutrient storage and dauer formation in an OGT-1 knockout. Proc. Natl. Acad. Sci. U.S.A. 102, 11266-11271. Abstract Article

Hanover, J.A., Yu, S., Lubas, W.B., Shin, S.H., Ragano-Caracciola, M., Kochran, J., and Love, D.C. (2003). Mitochondrial and nucleocytoplasmic isoforms of O-linked GlcNAc transferase encoded by a single mammalian gene. Arch. Biochem. Biophys. 409, 287-297. Abstract Article

Haslam, S.M., and Dell, A. (2003). Hallmarks of Caenorhabditis elegans N-glycosylation: complexity and controversy. Biochimie 85, 25-32. Abstract Article

Haslam, S.M., Gems, D., Morris, H.R., and Dell, A. (2002). The glycomes of Caenorhabditis elegans and other model organisms. Biochem. Soc. Symp., 117-134. Abstract

Haslam, S.M., Houston, K.M., Harnett, W., Reason, A.J., Morris, H.R., and Dell, A. (1999). Structural studies of $\mathrm{N}$-glycans of filarial parasites. Conservation of phosphorylcholine-substituted glycans among species and discovery of novel chito-oligomers. J. Biol. Chem. 274, 20953-20960. Abstract Article

Haslam, S.M., Khoo, K.H., Houston, K.M., Harnett, W., Morris, H.R., and Dell, A. (1997). Characterisation of the phosphorylcholine-containing N-linked oligosaccharides in the excretory-secretory $62 \mathrm{kDa}$ glycoprotein of Acanthocheilonema viteae. Mol. Biochem. Parasitol. 85, 53-66. Abstract Article

Hemmer, R.M., Donkin, S.G., Chin, K.J., Grenache, D.G., Bhatt, H., and Politz, S.M. (1991). Altered expression of an L1-specific, O-linked cuticle surface glycoprotein in mutants of the nematode Caenorhabditis elegans. J. Cell Biol. 115, 1237-1247. Abstract Article

Herman, T., Hartwieg, E., and Horvitz, H.R. (1999). sqv mutants of Caenorhabditis elegans are defective in vulval epithelial invagination. Proc. Natl. Acad. Sci. U.S.A. 96, 968-973. Abstract Article

Herman, T., and Horvitz, H.R. (1999). Three proteins involved in Caenorhabditis elegans vulval invagination are similar to components of a glycosylation pathway. Proc. Natl. Acad. Sci. U.S.A. 96, 974-979. Abstract Article

Herscovics, A. (1999). Importance of glycosidases in mammalian glycoprotein biosynthesis. Biochim. Biophys. Acta 1473, 96-107. Abstract

Hirschberg, C.B., Robbins, P.W., and Abeijon, C. (1998). Transporters of nucleotide sugars, ATP, and nucleotide sulfate in the endoplasmic reticulum and Golgi apparatus. Annu. Rev. Biochem. 67, 49-69. Abstract Article 
Hoflich, J., Berninsone, P., Gobel, C., Gravato-Nobre, M.J., Libby, B.J., Darby, C., Politz, S.M., Hodgkin, J., Hirschberg, C.B., and Baumeister, R. (2004). Loss of srf-3-encoded nucleotide sugar transporter activity in Caenorhabditis elegans alters surface antigenicity and prevents bacterial adherence. J. Biol. Chem. 279, 30440-30448. Abstract Article

Hudson, M.L., Kinnunen, T., Cinar, H.N., and Chisholm, A.D. (2006). C. elegans Kallmann syndrome protein KAL-1 interacts with syndecan and glypican to regulate neuronal cell migrations. Dev. Biol. 294, 352-365. Abstract Article

Hwang, H.Y., and Horvitz, H.R. (2002). The Caenorhabditis elegans vulval morphogenesis gene sqv-4 encodes a UDP-glucose dehydrogenase that is temporally and spatially regulated. Proc. Natl. Acad. Sci. U.S.A. 99, 14224-14229. Abstract Article

Hwang, H.Y., and Horvitz, H.R. (2002). The SQV-1 UDP-glucuronic acid decarboxylase and the SQV-7 nucleotide-sugar transporter may act in the Golgi apparatus to affect Caenorhabditis elegans vulval morphogenesis and embryonic development. Proc. Natl. Acad. Sci. U.S.A. 99, 14218-14223. Abstract Article

Hwang, H.Y., Olson, S.K., Brown, J.R., Esko, J.D., and Horvitz, H.R. (2003). The Caenorhabditis elegans genes $s q v-2$ and $s q v-6$, which are required for vulval morphogenesis, encode glycosaminoglycan galactosyltransferase II and xylosyltransferase. J. Biol. Chem. 278, 11735-11738. Abstract Article

Hwang, H.Y., Olson, S.K., Esko, J.D., and Horvitz, H.R. (2003). Caenorhabditis elegans early embryogenesis and vulval morphogenesis require chondroitin biosynthesis. Nature 423, 439-443. Abstract Article

Jones, J., Krag, S.S., and Betenbaugh, M.J. (2005). Controlling N-linked glycan site occupancy. Biochim. Biophys. Acta 1726, 121-137. Abstract Article

Jones, S.J., and Baillie, D.L. (1995). Characterization of the let-653 gene in Caenorhabditis elegans. Mol. Gen. Genet. 248, 719-726. Abstract Article

Ju, T., Zheng, Q., and Cummings, R.D. (2006). Identification of core 1 O-glycan T-synthase from Caenorhabditis elegans. Glycobiology 16, 947-958. Abstract Article

Kaji, H., Saito, H., Yamauchi, Y., Shinkawa, T., Taoka, M., Hirabayashi, J., Kasai, K., Takahashi, N., and Isobe, T. (2003). Lectin affinity capture, isotope-coded tagging and mass spectrometry to identify N-linked glycoproteins. Nat. Biotechnol. 21, 667-672. Abstract Article

Katic, I., Vallier, L.G., and Greenwald, I. (2005). New positive regulators of lin-12 activity in Caenorhabditis elegans include the BRE-5/Brainiac glycosphingolipid biosynthesis enzyme. Genetics 171, 1605-1615. Abstract Article

Kawar, Z.S., Van Die, I., and Cummings, R.D. (2002). Molecular cloning and enzymatic characterization of a UDP-GalNAc:GlcNAc(beta)-R beta1,4-N-acetylgalactosaminyltransferase from Caenorhabditis elegans. J. Biol. Chem. 277, 34924-34932. Abstract Article

Khoo, K.H., Maizels, R.M., Page, A.P., Taylor, G.W., Rendell, N.B., and Dell, A. (1991). Characterization of nematode glycoproteins: the major O-glycans of Toxocara excretory-secretory antigens are O-methylated trisaccharides. Glycobiology 1, 163-171. Abstract

Kimura, K.D., Tissenbaum, H.A., Liu, Y., and Ruvkun, G. (1997). daf-2, an insulin receptor-like gene that regulates longevity and diapause in Caenorhabditis elegans. Science 277, 942-946. Abstract Article

Kinnunen, T., Huang, Z., Townsend, J., Gatdula, M.M., Brown, J.R., Esko, J.D., and Turnbull, J.E. (2005). Heparan 2-O-sulfotransferase, hst-2, is essential for normal cell migration in Caenorhabditis elegans. Proc. Natl. Acad. Sci. U.S.A. 102, 1507-1512. Abstract Article 
Kitagawa, H., Egusa, N., Tamura, J.I., Kusche-Gullberg, M., Lindahl, U., and Sugahara, K. (2001). rib-2, a Caenorhabditis elegans homolog of the human tumor suppressor EXT genes encodes a novel alpha1,4-N-acetylglucosaminyltransferase involved in the biosynthetic initiation and elongation of heparan sulfate. J. Biol. Chem. 276, 4834-4838. Abstract Article

Kornfeld, R., and Kornfeld, S. (1985). Assembly of asparagine-linked oligosaccharides. Annu. Rev. Biochem. 54, 631-664. Abstract Article

Lochnit, G., Dennis, R.D., Ulmer, A.J., and Geyer, R. (1998). Structural elucidation and monokine-inducing activity of two biologically active zwitterionic glycosphingolipids derived from the porcine parasitic nematode Ascaris suum. J. Biol. Chem. 273, 466-474. Abstract Article

Lochnit, G., Dennis, R.D., Zahringer, U., and Geyer, R. (1997). Structural analysis of neutral glycosphingolipids from Ascaris suum adults (Nematoda: Ascaridida). Glycoconj. J. 14, 389-399. Abstract Article

Loukas, A., Hintz, M., Linder, D., Mullin, N.P., Parkinson, J., Tetteh, K.K., and Maizels, R.M. (2000). A family of secreted mucins from the parasitic nematode Toxocara canis bears diverse mucin domains but shares similar flanking six-cysteine repeat motifs. J. Biol. Chem. 275, 39600-39607. Abstract Article

Love, D.C., and Hanover, J.A. (2005). The hexosamine signaling pathway: deciphering the "O-GlcNAc code". Sci. STKE 2005, re13. Abstract Article

Lubas, W.A., Frank, D.W., Krause, M., and Hanover, J.A. (1997). O-Linked GlcNAc transferase is a conserved nucleocytoplasmic protein containing tetratricopeptide repeats. J. Biol. Chem. 272, 9316-9324. Abstract Article

Luhn, K., Wild, M.K., Eckhardt, M., Gerardy-Schahn, R., and Vestweber, D. (2001). The gene defective in leukocyte adhesion deficiency II encodes a putative GDP-fucose transporter. Nat. Genet. 28, 69-72. Abstract Article

Maizels, R.M., Burke, J., and Denham, D.A. (1987). Phosphorylcholine-bearing antigens in filarial nematode parasites: analysis of somatic extracts, in-vitro secretions and infection sera from Brugia malayi and B. pahangi. Parasite Immunol. 9, 49-66. Abstract

Marroquin, L.D., Elyassnia, D., Griffitts, J.S., Feitelson, J.S., and Aroian, R.V. (2000). Bacillus thuringiensis (Bt) toxin susceptibility and isolation of resistance mutants in the nematode Caenorhabditis elegans. Genetics 155, 1693-1699. Abstract

McClain, D.A., Lubas, W.A., Cooksey, R.C., Hazel, M., Parker, G.J., Love, D.C., and Hanover, J.A. (2002). Altered glycan-dependent signaling induces insulin resistance and hyperleptinemia. Proc. Natl. Acad. Sci. U.S.A. 99, 10695-10699. Abstract Article

Menzel, O., Vellai, T., Takacs-Vellai, K., Reymond, A., Mueller, F., Antonarakis, S.E., and Guipponi, M. (2004). The Caenorhabditis elegans ortholog of C21orf80, a potential new protein O-fucosyltransferase, is required for normal development. Genomics 84, 320-330. Abstract Article

Minniti, A.N., Labarca, M., Hurtado, C., and Brandan, E. (2004). Caenorhabditis elegans syndecan (SDN-1) is required for normal egg laying and associates with the nervous system and the vulva. J. Cell. Sci. 117, 5179-5190. Abstract Article

Mizuguchi, S., Uyama, T., Kitagawa, H., Nomura, K.H., Dejima, K., Gengyo-Ando, K., Mitani, S., Sugahara, K., and Nomura, K. (2003). Chondroitin proteoglycans are involved in cell division of Caenorhabditis elegans. Nature 423, 443-448. Abstract Article

Morelle, W., Haslam, S.M., Olivier, V., Appleton, J.A., Morris, H.R., and Dell, A. (2000). Phosphorylcholine-containing N-glycans of Trichinella spiralis: identification of multiantennary lacdiNAc structures. Glycobiology 10,941-950. Abstract Article

Morio, H., Honda, Y., Toyoda, H., Nakajima, M., Kurosawa, H., and Shirasawa, T. (2003). EXT gene family member rib-2 is essential for embryonic development and heparan sulfate biosynthesis in Caenorhabditis elegans. Biochem. Biophys. Res. Commun. 301, 317-323. Abstract Article 
Natsuka, S., Adachi, J., Kawaguchi, M., Nakakita, S., Hase, S., Ichikawa, A., and Ikura, K. (2002). Structural analysis of N-linked glycans in Caenorhabditis elegans. J. Biochem. (Tokyo) 131, 807-813. Abstract

Neuhaus, B., Bresciani, J., and Peters, W. (1997). Ultrastructure of the pharyngeal cuticle and lectin binding with wheat germ agglutinin-gold conjugate indicating chitin in the pharyngeal cuticle of Oesophagostomum dentatun (Strongylida, Nematoda). Acta Zool. 78, 205-213.

Nishiwaki, K., Hisamoto, N., and Matsumoto, K. (2000). A metalloprotease disintegrin that controls cell migration in Caenorhabditis elegans. Science 288, 2205-2208. Abstract Article

Nishiwaki, K., Kubota, Y., Chigira, Y., Roy, S.K., Suzuki, M., Schvarzstein, M., Jigami, Y., Hisamoto, N., and Matsumoto, K. (2004). An NDPase links ADAM protease glycosylation with organ morphogenesis in C. elegans. Nat. Cell Biol. 6, 31-37. Abstract Article

O'Donnell, N., Zachara, N.E., Hart, G.W., and Marth, J.D. (2004). Ogt-dependent X-chromosome-linked protein glycosylation is a requisite modification in somatic cell function and embryo viability. Mol. Cell. Biol. 24, 1680-1690. Abstract Article

Olson, S.K., Bishop, J.R., Yates, J.R., Oegema, K., and Esko, J.D. (2006). Identification of novel chondroitin proteoglycans in Caenorhabditis elegans: embryonic cell division depends on CPG-1 and CPG-2. J. Cell Biol. 173, 985-994. Abstract Article

Paschinger, K., Rendic, D., Lochnit, G., Jantsch, V., and Wilson, I.B. (2004). Molecular basis of anti-horseradish peroxidase staining in Caenorhabditis elegans. J. Biol. Chem. 279, 49588-49598. Abstract Article

Paschinger, K., Staudacher, E., Stemmer, U., Fabini, G., and Wilson, I.B. (2005). Fucosyltransferase substrate specificity and the order of fucosylation in invertebrates. Glycobiology 15, 463-474. Abstract Article

Rhiner, C., Gysi, S., Frohli, E., Hengartner, M.O., and Hajnal, A. (2005). Syndecan regulates cell migration and axon guidance in C. elegans. Development 132, 4621-4633. Abstract Article

Riddle, D.L. (1977). A genetic pathway for dauer larva formation in C. elegans. Stadler Genetics Symposium 9, $101-120$.

Rogalski, T.M., Williams, B.D., Mullen, G.P., and Moerman, D.G. (1993). Products of the unc-52 gene in Caenorhabditis elegans are homologous to the core protein of the mammalian basement membrane heparan sulfate proteoglycan. Genes Dev. 7, 1471-1484. Abstract

Schachter, H. (2004). Protein glycosylation lessons from Caenorhabditis elegans. Curr. Opin. Struct. Biol. 14, 607-616. Abstract Article

Schachter, H., Chen, S., Zhang, W., Spence, A.M., Zhu, S., Callahan, J.W., Mahuran, D.J., Fan, X., Bagshaw, R.D., She, Y.M., et al. (2002). Functional post-translational proteomics approach to study the role of N-glycans in the development of Caenorhabditis elegans. Biochem. Soc. Symp., 1-21. Abstract

Shafi, R., Iyer, S.P., Ellies, L.G., O'Donnell, N., Marek, K.W., Chui, D., Hart, G.W., and Marth, J.D. (2000). The O-GlcNAc transferase gene resides on the X chromosome and is essential for embryonic stem cell viability and mouse ontogeny. Proc. Natl. Acad. Sci. U.S.A. 97, 5735-5739. Abstract Article

Spiro, R.G. (2002). Protein glycosylation: nature, distribution, enzymatic formation, and disease implications of glycopeptide bonds. Glycobiology 12, 43R-56R. Abstract Article

Sugimoto, A., Hozak, R.R., Nakashima, T., Nishimoto, T., and Rothman, J.H. (1995). dad-1, an endogenous programmed cell death suppressor in Caenorhabditis elegans and vertebrates. EMBO J. 14, 4434-4441. Abstract

Toyoda, H., Kinoshita-Toyoda, A., and Selleck, S.B. (2000). Structural analysis of glycosaminoglycans in Drosophila and Caenorhabditis elegans and demonstration that tout-velu, a Drosophila gene related to EXT tumor suppressors, affects heparan sulfate in vivo. J. Biol. Chem. 275, 2269-2275. Abstract Article 
Turnbull, J., Powell, A., and Guimond, S. (2001). Heparan sulfate: decoding a dynamic multifunctional cell regulator. Trends Cell Biol. 11, 75-82. Abstract Article

Uccelletti, D., O'Callaghan, C., Berninsone, P., Zemtseva, I., Abeijon, C., and Hirschberg, C.B. (2004). ire-1-dependent transcriptional up-regulation of a lumenal uridine diphosphatase from Caenorhabditis elegans. J. Biol. Chem. 279, 27390-27398. Abstract Article

Varki, A. (1993). Biological roles of oligosaccharides: all of the theories are correct. Glycobiology 3, 97-130. Abstract

Varki, A., Cummings, R., Esko, J., Freeze, H., Hart, G., and Marth, J. (1999). Essentials of Glycobiology (NY, Cold Spring Harbor).

Veronico, P., Gray, L.J., Jones, J.T., Bazzicalupo, P., Arbucci, S., Cortese, M.R., Di Vito, M., and De Giorgi, C. (2001). Nematode chitin synthases: gene structure, expression and function in Caenorhabditis elegans and the plant parasitic nematode Meloidogyne artiellia. Mol. Genet. Genomics 266, 28-34. Abstract Article

Vosseller, K., Wells, L., Lane, M.D., and Hart, G.W. (2002). Elevated nucleocytoplasmic glycosylation by O-GlcNAc results in insulin resistance associated with defects in Akt activation in 3T3-L1 adipocytes. Proc. Natl. Acad. Sci. U.S.A. 99, 5313-5318. Abstract Article

Wang, H., Spang, A., Sullivan, M.A., Hryhorenko, J., and Hagen, F.K. (2005). The terminal phase of cytokinesis in the Caenorhabditis elegans early embryo requires protein glycosylation. Mol. Biol. Cell 16, 4202-4213. Abstract Article

Warren, C.E., Krizus, A., and Dennis, J.W. (2001). Complementary expression patterns of six nonessential Caenorhabditis elegans core 2/I N-acetylglucosaminyltransferase homologues. Glycobiology 11, 979-988. Abstract Article

Warren, C.E., Krizus, A., Partridge, E.A., and Dennis, J.W. (2002). Caenorhabditis elegans gly-1, a core 2/I $\mathrm{N}$-acetylglucosaminyltransferase homologue, is a glucosyltransferase. Glycobiology $12,8 \mathrm{G}-9 \mathrm{G}$.

Warren, C.E., Krizus, A., Roy, P.J., Culotti, J.G., and Dennis, J.W. (2002). The Caenorhabditis elegans gene, gly-2, can rescue the N-acetylglucosaminyltransferase V mutation of Lec4 cells. J. Biol. Chem. 277, 22829-22838. Abstract Article

Wells, L., Vosseller, K., and Hart, G.W. (2001). Glycosylation of nucleocytoplasmic proteins: signal transduction and O-GlcNAc. Science 291, 2376-2378. Abstract Article

Wharton, D. (1980). Nematode egg-shells. Parasitology 81, 447-463. Abstract

Yamada, S., Van Die, I., Van den Eijnden, D.H., Yokota, A., Kitagawa, H., and Sugahara, K. (1999). Demonstration of glycosaminoglycans in Caenorhabditis elegans. FEBS Lett. 459, 327-331. Abstract Article

Zhang, W., Cao, P., Chen, S., Spence, A.M., Zhu, S., Staudacher, E., and Schachter, H. (2003). Synthesis of paucimannose $\mathrm{N}$-glycans by Caenorhabditis elegans requires prior actions of UDP-N-acetyl-D-glucosamine: alpha-3-D-mannoside beta1,2-N-acetylglucosaminyltransferase I, alpha3,6-mannosidase II and a specific membrane-bound beta-N-acetylglucosaminidase. Biochem. J. 372, 53-64. Abstract Article

Zhang, Y., Foster, J.M., Nelson, L.S., Ma, D., and Carlow, C.K. (2005). The chitin synthase genes $c h s-1$ and chs-2 are essential for $C$. elegans development and responsible for chitin deposition in the eggshell and pharynx, respectively. Dev. Biol. 285, 330-339. Abstract Article

Zheng, Q., Van Die, I., and Cummings, R.D. (2002). Molecular cloning and characterization of a novel alpha 1,2-fucosyltransferase (CE2FT-1) from Caenorhabditis elegans. J. Biol. Chem. 277, 39823-39832. Abstract Article 


\section{A. Appendix 1}

This Appendix includes putative glycosylation genes based on homology to genes from other species. Activity refers to presumed biochemical function, except those entries indicated with *, for which the C. elegans gene has been expressed and its biochemical activity has been demonstrated. Adapted from Schachter (2004).

\begin{tabular}{|c|c|c|c|c|}
\hline Activity & C. elegans gene & Mutant phenotype & $\begin{array}{c}\text { RNAi } \\
\text { phenotype }\end{array}$ & Reference(s) \\
\hline \multicolumn{5}{|c|}{ Genes involved in synthesis and modification of GAG (Xyl-Ser O-glycans) } \\
\hline UDP-GlcA decarboxylase * & $\mathrm{D} 2096.4(s q v-1)$ & $\begin{array}{c}\text { Squashed vulva, } \\
\text { hermaphrodite } \\
\text { sterile }\end{array}$ & WT & $\begin{array}{l}\text { Hwang and } \\
\text { Horvitz, } 2002\end{array}$ \\
\hline$\beta$ gal $\beta 1,3-$ GalT II * & $\begin{array}{l}\text { Y110A2AL.14 } \\
(s q v-2)\end{array}$ & $\begin{array}{c}\text { Squashed vulva, } \\
\text { hermaphrodite } \\
\text { sterile }\end{array}$ & $\begin{array}{l}\text { Clr, Cyk, Egl, } \\
\text { Sma }\end{array}$ & $\begin{array}{l}\text { Hwang et al., } \\
\text { 2003; Wang et } \\
\text { al., } 2005\end{array}$ \\
\hline Xyl-prot $\beta 1,4-G a l T *$ & R10E11.4 (sqv-3) & $\begin{array}{l}\text { Squashed vulva, } \\
\text { hermaphrodite } \\
\text { sterile }\end{array}$ & & Bulik et al., 2000 \\
\hline UDP-Glc dehydrogenase * & F29F11.1 (sqv-4) & $\begin{array}{c}\text { Squashed vulva, } \\
\text { hermaphrodite } \\
\text { sterile }\end{array}$ & Emb & $\begin{array}{l}\text { Hwang and } \\
\text { Horvitz, } 2002\end{array}$ \\
\hline $\begin{array}{c}\beta 1,4 \mathrm{GalNAcT} \mathrm{I} / \mathrm{II} \text { (chondroitin } \\
\text { synthase) * }\end{array}$ & T24D11.1a,b $(s q v-5)$ & $\begin{array}{l}\text { Squashed vulva, } \\
\text { hermaphrodite } \\
\text { sterile }\end{array}$ & & $\begin{array}{l}\text { Hwang et al., } \\
\text { 2003; Mizuguchi } \\
\text { et al., } 2003\end{array}$ \\
\hline Polypeptide $\beta$-XylT * & Y50D4C.4 (sqv-6) & $\begin{array}{c}\text { Squashed vulva, } \\
\text { hermaphrodite } \\
\text { sterile }\end{array}$ & Cyk & $\begin{array}{l}\text { Hwang et al., } \\
2003\end{array}$ \\
\hline Gal-Gal-Xyl-S $\beta 1,3$ GlcAT * & ZK1307.5 (sqv-8) & $\begin{array}{c}\text { Squashed vulva, } \\
\text { hermaphrodite } \\
\text { sterile }\end{array}$ & & Bulik et al., 2000 \\
\hline Heparan sulfate synthesis & F12F6.3 (rib-1) & Abnormal & WT & $\begin{array}{l}\text { Kitagawa et al., } \\
2001\end{array}$ \\
\hline $\begin{array}{c}\alpha 1,4-G n T \text { I/II (heparan sulfate } \\
\text { synthesis) } *\end{array}$ & K01G5.6 (rib-2) & Abnormal & WT & $\begin{array}{l}\text { Kitagawa et al., } \\
2001\end{array}$ \\
\hline \multirow[t]{2}{*}{ GlcAT/GlcT/GalT? } & B0310.5 & & WT & \\
\hline & F08G5.5 & & WT & \\
\hline D-GlcA C5-epimerase & $\mathrm{B} 0285.5(h s e-5)$ & $\begin{array}{l}\text { Axon, cell guidance } \\
\text { defects }\end{array}$ & WT & $\begin{array}{l}\text { Bulow and } \\
\text { Hobert, } 2004\end{array}$ \\
\hline $\begin{array}{c}\text { Heparan sulfate } \\
\text { N-deacetylase/N-sulfotransferase }\end{array}$ & F08B4.6 (hst-1) & Abnormal & WT/Emb, Ste & \\
\hline Heparan sulfate 2O-sulfotransferase & C34F6.4 (hst-2) & $\begin{array}{l}\text { Axon, cell guidance } \\
\text { defects }\end{array}$ & Mig, Egl & $\begin{array}{c}\text { Bulow and } \\
\text { Hobert, 2004; } \\
\text { Kinnunen et al., } \\
2005\end{array}$ \\
\hline Heparan sulfate 6O-sulfotransferase & Y34B4A.3 (hst-6) & $\begin{array}{l}\text { Axon, cell guidance } \\
\text { defects }\end{array}$ & WT & $\begin{array}{c}\text { Bulow and } \\
\text { Hobert, } 2004\end{array}$ \\
\hline \multicolumn{5}{|l|}{ Genes involved in N-glycan synthesis } \\
\hline \multicolumn{5}{|l|}{ Synthesis of the lipid linked precursor } \\
\hline ALG7 & T08D2.2 & & WT & \\
\hline
\end{tabular}




\begin{tabular}{|c|c|c|c|c|}
\hline Activity & C. elegans gene & Mutant phenotype & $\begin{array}{c}\text { RNAi } \\
\text { phenotype }\end{array}$ & Reference(s) \\
\hline & Y60A3A.13 & & WT & \\
\hline ALG1 & T26A5.4 & & WT/Emb,Ste & \\
\hline ALG2 & $\mathrm{T} 23 \mathrm{~F} 2.1$ & & WT/Abn & \\
\hline ALG3 & K09E4.2 & & WT & \\
\hline ALG6 & C08B11.8 & & WT & \\
\hline ALG8 & C08H9.3 & & WT/Emb, Lva & \\
\hline ALG9 & C14A4.3 & & WT & \\
\hline ALG10 & T24D1.4 & & WT & \\
\hline $\begin{array}{c}\text { Lec35/Monosaccharide-P-dolichol } \\
\text { utilization }\end{array}$ & F38E1.9 & & $\begin{array}{l}\text { Let, Gro, } \\
\text { Bmd, Lva }\end{array}$ & \\
\hline \multicolumn{5}{|l|}{ Oligosaccharyltransferase complex } \\
\hline OST1/ribophorin & T22D1.4 & & WT/ Abn & Wang et al., 2005 \\
\hline Ribophorin II & M01A10.3 & & WT/Abn & \\
\hline OST3 & ZK686.3 & & WT/Abn & \\
\hline WBP1/DDOST/Ost48 & T09A5.11 & & $\begin{array}{c}\text { Emb, Gro, } \\
\text { Lon, Lvl, Unc }\end{array}$ & \\
\hline OST2/DAD-1 & F57B10.10 (dad-1) & & $\begin{array}{l}\text { Emb, Gro, } \\
\text { Lva, Unc }\end{array}$ & $\begin{array}{c}\text { DAD-1 } \\
\text { suppresses } \\
\text { programmed cell } \\
\text { death (Sugimoto } \\
\text { et al., 1995) }\end{array}$ \\
\hline STT3 & T12A2.2 & & $\begin{array}{l}\text { Emb, Lva, } \\
\text { Lon, Ste }\end{array}$ & \\
\hline \multicolumn{5}{|l|}{ Processing glycosydases } \\
\hline$\alpha 1,2$ glycosidase I & F13H10.4 & & WT/Abn & \\
\hline$\alpha 1,3$ glycosidase II & F40F9.6a,b & & Emb, Lva & \\
\hline \multirow[t]{4}{*}{$\alpha 1,2$ mannosidase I } & C47E12.3 & & WT & \\
\hline & T03G11.4 & & WT & \\
\hline & ZC410.3 & & WT/Emb & \\
\hline & ZC506.1 & & WT & \\
\hline$\alpha$ 3,6 mannosidase II & F48C1.1a,b & & WT & \\
\hline \multicolumn{5}{|l|}{ Quality control glycosyltransferases } \\
\hline \multirow[t]{2}{*}{ Glycoprotein GlcT } & F26H9.8 & & WT & \\
\hline & F48E3.3 & & WT & \\
\hline \multicolumn{5}{|c|}{$\mathrm{N}$-acetylglycosaminyltransferases specific for the synthesis of complex $\mathrm{N}$-glycans } \\
\hline \multirow[t]{3}{*}{$\beta 1,2 \mathrm{GnT} \mathrm{I} *$} & B0416.6 (gly-13) & $\mathrm{WT}$ & WT & Chen et al., 1999 \\
\hline & F48E3.1a,b (gly-12) & WT & Abn & \\
\hline & M01F1.1 (gly-14) & WT & WT & \\
\hline$\beta 1,2 \mathrm{GnT} \mathrm{II} *$ & C03E10.4 (gly-20) & WT & WT & Chen et al., 2002 \\
\hline$\beta 1,6 \mathrm{GnT} \mathrm{V} *$ & C55B7.2 (gly-2) & WT & $\mathrm{WT} / \mathrm{Emb}$ & $\begin{array}{l}\text { Warren et al., } \\
2002\end{array}$ \\
\hline
\end{tabular}




\begin{tabular}{|c|c|c|c|c|}
\hline Activity & C. elegans gene & Mutant phenotype & $\begin{array}{c}\text { RNAi } \\
\text { phenotype }\end{array}$ & Reference(s) \\
\hline \multicolumn{5}{|l|}{ N-Glycan core fucosyltransferase } \\
\hline Gn-Asn-X $\alpha 1,6$ FucT & C10F3.6 (fut-8) & & WT & $\begin{array}{l}\text { Paschinger et al., } \\
2005\end{array}$ \\
\hline $\begin{array}{c}\text { Gal(NAc) } \beta 1,4 \mathrm{Gn}(\mathrm{Fuc} \text { to } \mathrm{Gn}) \\
\alpha 1,3 \mathrm{FucT} *\end{array}$ & K08F8.3 (fut-1) & WT & WT & $\begin{array}{l}\text { Paschinger et al., } \\
2004\end{array}$ \\
\hline \multicolumn{5}{|c|}{ Genes specific for GalNAc Ser/Thr O-glycan synthesis } \\
\hline \multirow[t]{9}{*}{ Polypeptide GalNAcT * } & ZK688.8 (gly-3) & & WT & $\begin{array}{l}\text { Hagen and } \\
\text { Nehrke, } 1998\end{array}$ \\
\hline & $\begin{array}{l}\text { Y116F11B.12.a,b } \\
\quad(g l y-4)\end{array}$ & & WT & Wang et al., 2005 \\
\hline & $\begin{array}{l}\text { Y39E4B.12a,b,c } \\
\quad(g l y-5)\end{array}$ & & WT & \\
\hline & H38K22.5a (gly-6) & & WT & \\
\hline & Y46H3A.6 (gly-7) & & WT & \\
\hline & Y66A7A.6 (gly-8) & & WT & \\
\hline & Y47D3A.23(gly-9) & & WT & \\
\hline & Y45F10D.3 (gly-10) & & WT & \\
\hline & Y75B8A.9 (gly-11) & & WT & \\
\hline \multicolumn{5}{|c|}{ GalNAc $\alpha$ 1-O-S/T $\beta$ 1,3GalT (O-glycan core 1 ) } \\
\hline \multirow[t]{8}{*}{ Core $1 \beta 3$-Gal-T or T-synthase* } & $\mathrm{C} 38 \mathrm{H} 2.2$ & & WT & Ju et al., 2006 \\
\hline & C02H6.1 & & WT & \\
\hline & C16D9.6 & & WT & \\
\hline & T22B11.2 & & WT & \\
\hline & Y38C1AB.1 & & WT & \\
\hline & Y38C1AB.5 & & WT & \\
\hline & ZC250.2 & & WT & \\
\hline & C17A2.3 & & WT & \\
\hline \multicolumn{5}{|c|}{ Homology to O-glycan core $1 \beta 1,3$ GalT/core $2 \beta 1,6$ GnT } \\
\hline & T09E11.6 & & WT & \\
\hline \multicolumn{5}{|c|}{ Genes for GalNAc Ser/Thr O-glycan synthesis and possibly other pathways } \\
\hline \multicolumn{4}{|c|}{$\begin{array}{l}\text { Gal } \beta 1,3 \text { GalNAca1-O-S/T (Gn to GalNAc) } \beta 1,6-G n T \text { (O-glycan core } 2 \text { ); homologous to } \beta 1,6 \\
\text { IGnT }\end{array}$} & $\begin{array}{l}\text { Warren et al., } \\
2001\end{array}$ \\
\hline & F44F4.6 (gly-1) & WT & WT & $\begin{array}{c}\text { Warren et al., } \\
2002 ; \text { gly- } 1 \text { does } \\
\text { not encode core } 2 \\
\beta 1,6 \text { GnT, but } \\
\text { rather a } \beta 1,6 \\
\text { GlcT }\end{array}$ \\
\hline & C54C8.11 (gly-15) & & WT & \\
\hline & T15D6.2 (gly-16) & WT & WT & \\
\hline & T15D6.3 (gly-17) & & WT & \\
\hline & F22D6.11 (gly-18) & WT & WT & \\
\hline & F22D6.12 (gly-19) & & WT & \\
\hline
\end{tabular}




\begin{tabular}{|c|c|c|c|c|}
\hline Activity & C. elegans gene & Mutant phenotype & $\begin{array}{c}\text { RNAi } \\
\text { phenotype }\end{array}$ & Reference(s) \\
\hline & T09E11.9 & & WT & \\
\hline & R07B7.6 & & WT & \\
\hline & F30A10.4 & & WT & \\
\hline & F35H8.2 & & & \\
\hline \multicolumn{5}{|l|}{ Other galactosyltransferases } \\
\hline \multirow[t]{12}{*}{$\beta \mathrm{Gn} \beta 1,3$-GalT } & F14B6.6 & & WT/Gro & \\
\hline & K08D12.5 & & WT & \\
\hline & C47F8.3 & & WT & \\
\hline & C47F8.6 & & WT & \\
\hline & T09E11.11 & & WT & \\
\hline & T09F5.1 & & WT & \\
\hline & E03H4.11 & & WT & \\
\hline & T15D6.5 & & WT & \\
\hline & F14B6.4 & & WT & \\
\hline & $\begin{array}{l}\text { T09E11.10 } \\
\text { ( } \beta 1,3-G n T ?)\end{array}$ & & WT & \\
\hline & $\begin{array}{c}\text { C47F8.5 } \\
(\beta 1,3-G n T ?)\end{array}$ & & WT & \\
\hline & $\begin{array}{c}\text { C54C8.3 } \\
(\beta 1,3 \text {-GnT?) }\end{array}$ & & WT & \\
\hline$\beta$ Gn $\beta 1,4-G a l T$ & W02B12.11 & & WT & \\
\hline \multicolumn{5}{|c|}{ Other N-acetylhexosaminyltransferases } \\
\hline \multirow[t]{2}{*}{ Chitin Gn-T } & T25G3.2 (chi-1) & Emb & Emb. Gro,Ste & $\begin{array}{l}\text { Veronico et al., } \\
\text { 2001; Zhang et } \\
\text { al., } 2005\end{array}$ \\
\hline & F48A11.1 (chs-2) & & $\begin{array}{l}\text { Bmd, Emb, } \\
\text { Gro, Unc }\end{array}$ & $\begin{array}{c}\text { Veronico et al., } \\
\text { 2001; Zhang et } \\
\text { al., } 2005\end{array}$ \\
\hline Gal $\beta 1,4 \mathrm{Gnb} \beta 1,3-\mathrm{GnT}$ & C18G1.3 & & WT & \\
\hline O-Gn transferase * & K04G7.3 (ogt-1) & $\begin{array}{l}\text { Viable; suppressed } \\
\text { constitutive dauer } \\
\text { formation }\end{array}$ & & $\begin{array}{l}\text { Hanover et al., } \\
2005\end{array}$ \\
\hline Gal $\beta 1,4$ GlcCer $\beta 1,3-G n T$ & F48F7.3 & & WT & \\
\hline Protein O-Man $\beta 1,2-\mathrm{GnT} 1$ & M70.4a,b & & WT & \\
\hline \multicolumn{5}{|c|}{ Genes involved in the biosynthesis of glycosphingolipids } \\
\hline$\beta \mathrm{Gn} \beta 1,3-\mathrm{GalT}$ & Y39E4B.9 (bre-2) & Bt resistant & WT & $\begin{array}{l}\text { Griffitts et al., } \\
2005\end{array}$ \\
\hline Glcb1-Cer $\beta 1,4-$ Man-T & B0464.3 (bre-3) & Bt resistant & & $\begin{array}{l}\text { Griffitts et al., } \\
2005\end{array}$ \\
\hline GnbR $\beta 1,4-$ GalNAcT & Y73E7A.7 (bre-4) & Bt resistant & & $\begin{array}{l}\text { Griffitts et al., } \\
\text { 2005; Kawar et } \\
\text { al., } 2002\end{array}$ \\
\hline
\end{tabular}




\begin{tabular}{|c|c|c|c|c|}
\hline Activity & C. elegans gene & Mutant phenotype & $\begin{array}{c}\text { RNAi } \\
\text { phenotype }\end{array}$ & Reference(s) \\
\hline Man $\beta 1,4$ GlcR $\beta 1,3-G n T$ & T12G3.8 (bre-5) & $\begin{array}{c}\text { Bt resistant } \\
\text { Suppresses Egl } \\
\text { defect associated } \\
\text { with elevated lin-12 } \\
\text { activity. }\end{array}$ & & $\begin{array}{l}\text { Griffitts et al., } \\
\text { 2005; Katic et al., } \\
2005\end{array}$ \\
\hline \multirow[t]{2}{*}{ Cer GlcT } & F59G1.1a,b,c,d & & WT & \\
\hline & F20B4.6 & & WT & \\
\hline \multicolumn{5}{|l|}{ Other fucosyltransferases } \\
\hline \multicolumn{5}{|l|}{ Gal $\beta R \alpha 1,2-F u c T$} \\
\hline & EGAP9.2 (fut-2) & WT & WT & $\begin{array}{l}\text { Zheng et al., } \\
2002\end{array}$ \\
\hline & B0205.4 & & & \\
\hline & C06E1.7 & & WT & \\
\hline & C14C6.3 & & WT & \\
\hline & C17A2.4 & & WT & \\
\hline & C18G1.8 & & WT & \\
\hline & EGAP9.3 & & WT & \\
\hline & F08A8.5 & & WT & \\
\hline & F11A5.5 & & WT & \\
\hline & F17B5.4 & & WT & \\
\hline & F31F4.11 & & WT & \\
\hline & F31F4.17 & & WT & \\
\hline & K06H6.6 & & WT & \\
\hline & T26E4.3 & & WT & \\
\hline & T26E4.4 & & WT & \\
\hline & T26E4.5 & & WT & \\
\hline & T26H5.8 & & WT & \\
\hline & T28A8.2 & & WT & \\
\hline & T28F2.1 & & WT & \\
\hline & W07G4.2 & & WT & \\
\hline & Y5H2B.1 & & WT & \\
\hline & F41D3.6 (galectin?) & & WT & \\
\hline \multicolumn{5}{|c|}{ Gal $\beta 1,4 / 3 \mathrm{Gn}$ (Fuc to Gn) $\alpha 1,3 / 4-F u c T$ (Lewis x or a) } \\
\hline & F59E12.13 (fut-3) & WT & WT & \\
\hline & K12H6.3 (fut-4) & WT & WT & \\
\hline & T05A7.10 (fut-5) & & & \\
\hline & T05A7.5 (fut-6) & WT & WT & \\
\hline \multirow[t]{2}{*}{ Protein O-FucT } & $\mathrm{C} 15 \mathrm{C} 7.7$ & & WT & Wang et al., 2005 \\
\hline & K10G9.3 (pad-2) & & $\begin{array}{l}\text { Egl, Bmd, } \\
\text { Let,Evl }\end{array}$ & $\begin{array}{c}\text { Menzel et al., } \\
2004\end{array}$ \\
\hline
\end{tabular}




\begin{tabular}{|c|c|c|c|c|}
\hline Activity & C. elegans gene & Mutant phenotype & $\begin{array}{c}\text { RNAi } \\
\text { phenotype }\end{array}$ & Reference(s) \\
\hline \multicolumn{5}{|c|}{ Nucleotide sugar transport / antiporter cycle } \\
\hline $\begin{array}{l}\text { UDP-GlcA/UDP-Gal/UDP-GalNAc } \\
\text { transporter * }\end{array}$ & C52E12.3 (sqv-7) & Squashed vulva & $\mathrm{WT} / \mathrm{Emb}$ & $\begin{array}{c}\text { Berninsone et al., } \\
2001\end{array}$ \\
\hline$\underset{*}{\text { UDP-Gal/UDP-GlcNAc transporter }}$ & M02B1.1 (srf-3) & $\begin{array}{l}\text { Abnormal surface } \\
\text { reactivity }\end{array}$ & & $\begin{array}{l}\text { Hoflich et al., } \\
2004\end{array}$ \\
\hline GDP-Fuc transporter * & C50F4.14 & & WT & Luhn et al., 2001 \\
\hline Putative nucleotide sugar transporter & F15B10.1 & & WT & \\
\hline Putative nucleotide sugar transporter & ZC250.3 & & WT/Abn & \\
\hline Putative nucleotide sugar transporter & K02E10.5 & & WT & \\
\hline $\begin{array}{l}\text { UDP-GlcNAc/UDP-GalNAc } \\
\text { transporter* }\end{array}$ & C03H5.2 & & WT/Ste & $\begin{array}{l}\text { Caffaro et al., } \\
2006\end{array}$ \\
\hline Putative nucleotide sugar transporter & ZK896.9 & & WT & \\
\hline E-NTPDase * & R07E4.4 (mig-23) & $\begin{array}{l}\text { Defective DTC } \\
\text { migration }\end{array}$ & WT & $\begin{array}{c}\text { Nishiwaki et al., } \\
2004\end{array}$ \\
\hline E-NTPDase * & K08H10.4 (uda-1) & & WT & $\begin{array}{l}\text { Uccelletti et al., } \\
2004\end{array}$ \\
\hline E-NTPDase * & C33H5.14 & & WT & $\begin{array}{l}\text { Uccelletti et al., } \\
2004\end{array}$ \\
\hline E-NTPDase & F08C6.6 & & WT & \\
\hline \multicolumn{5}{|l|}{ Nucleotide sugar synthesis } \\
\hline UDP-Gn 2 epimerase & D2007.5 & & WT & \\
\hline \multirow[t]{2}{*}{ GDP-Man pyrophosphorylase } & C15F1.4 (ppp-1) & & Abn & \\
\hline & Y47D9A.1a,b & & WT & \\
\hline P-Man mutase 2 & F52B11.2 & & WT/Gro & \\
\hline \multirow[t]{3}{*}{ P-Glc mutase/P-Man mutase } & F21D5.1 & & Emb, Osm & \\
\hline & R05F9.6 & & $\mathrm{WT} / \mathrm{Emb}$ & \\
\hline & Y43F4B.5a,b & & WT/Emb/Gro & \\
\hline \multirow[t]{2}{*}{ P-Man isomerase } & $\mathrm{C} 05 \mathrm{C} 8.7$ & & $\begin{array}{c}\text { WT/Emb, } \\
\text { Lva, Sck, Ste }\end{array}$ & \\
\hline & ZK632.4 & & WT & \\
\hline UDP-Glu/UDP-Gal 4-epimerase & C47B2.6 & & WT & \\
\hline \multirow[t]{2}{*}{ Gal-1-phosphate uridyltransferase } & Y55D5A.2 & & & \\
\hline & ZK1058.3 & & WT & \\
\hline GDP-Man 4,6-dehydratase & F56H6.5 & & WT/ Abn & \\
\hline UDP-galactopyranose mutase & H04M03.4 & & & \\
\hline \multicolumn{5}{|l|}{ Other glycosidases } \\
\hline$\alpha$-mannosidase & F55D10.1 & & WT & \\
\hline Endo- $\beta \mathrm{N}$-acetylglucosaminidase $*$ & F01F1.10a,b & & WT & \\
\hline O-Gn selective $\beta$-Gnase & T20B5.3 (oga-1) & & WT & $\begin{array}{l}\text { Forsythe et al., } \\
2006\end{array}$ \\
\hline
\end{tabular}

All WormBook content, except where otherwise noted, is licensed under a Creative Commons Attribution License. 